\title{
TSH-secreting pituitary adenoma: benefits of pre-operative octreotide
}

\author{
I R Wallace', E Healy ${ }^{2}$, R S Cooke ${ }^{3}$, P K Ellis ${ }^{4}$, R Harper ${ }^{5}$ and S J Hunter ${ }^{1}$ \\ ${ }^{1}$ Regional Centre for Endocrinology and Diabetes ${ }^{2}$ Department of Neuropathology ${ }^{3}$ Department of Neurosurgery \\ ${ }^{4}$ Department of Radiology, Royal Victoria Hospital, Grosvenor Road, Belfast BT12 6BA, UK \\ ${ }^{5}$ Department of Endocrinology and Diabetes, Ulster Hospital, Dundonald BT16 1RH, UK
}

Correspondence

should be addressed

to I R Wallace

Email

iwallace01@qub.ac.uk

\section{Summary}

TSH-secreting pituitary adenomas are rare and the optimal investigation and management is uncertain. We describe a case of a 43 year-old woman with a TSH-secreting pituitary adenoma, highlighting diagnostic testing and our use, pre-operatively of somatostatin analogue therapy, which induced biochemical euthyroidism and a reduction in tumour size.

\section{Learning points:}

- The differential diagnosis of the syndrome of inappropriate TSH secretion is non-thyroidal illness, medications, assay interference due to heterophilic antibodies, thyroid hormone resistance and TSH-secreting pituitary adenoma.

- TRH stimulation test and triiodothyronine suppression test assist in differentiating thyroid hormone resistance and TSH-secreting pituitary adenoma.

- Somatostatin analogue therapy can induce biochemical euthyroidism and reduce tumour size.

\section{Background}

Thyrotropin (TSH)-secreting pituitary adenomas are rare accounting for $0.5-1 \%$ of all pituitary adenomas with an estimated prevalence of 1 per million (1). We describe the effects of pre-operative octreotide in a single case.

\section{Case presentation}

A 43 year-old woman presented with a 3 month history of three stone weight loss, palpitations, anxiety, heat intolerance, sleep disturbance, tremor and increased energy. She had initially attributed her symptoms to stress, working in a full-time administrative role, she was a widow with three teenage daughters and also ran seven miles on alternate days. She denied headaches or visual disturbance. She was on no regular medications and was otherwise well. Her sister was receiving carbimazole as treatment for autoimmune primary hyperthyroidism. On examination she had no evidence of dysthyroid eye disease and no goitre with visual fields intact to confrontation.

\section{Investigation}

Initial thyroid biochemistry revealed a free thyroxine $\left(\mathrm{T}_{4}\right)$ concentration $29.5 \mathrm{pmol} / \mathrm{l}$ (reference range 9.0$19.0 \mathrm{pmol} / \mathrm{l}$ ), TSH concentration $3.672 \mathrm{mU} / \mathrm{l}$ (reference range $0.4-4.5 \mathrm{mU} / \mathrm{l})$ and free triiodothyronine $\left(\mathrm{T}_{3}\right)$ concentration $6.5 \mathrm{nmol} / \mathrm{l}$ (reference range 0.9$2.5 \mathrm{nmo} / \mathrm{l})$. This abnormality persisted when serum was reanalysed using an alternative assay. Assay interference was excluded by polyethylene glycol (PEG) precipitation.

Markers of peripheral thyroid hormone activity including sex hormone binding globulin $90 \mathrm{nmol} / \mathrm{l}$ (reference range $20-115 \mathrm{nmol} / \mathrm{l}$ ), total cholesterol, angiotensin converting enzyme and ferritin concentrations were all within the normal reference ranges. 
An ultrasound of thyroid demonstrated a hypervascular gland, with a peak systolic velocity of $13-17 \mathrm{~cm} / \mathrm{s}$. $\alpha$-subunit concentration was $1.1 \mathrm{IU} / 1$ (reference range $<1.0 \mathrm{IU} / \mathrm{l})$, follicle-stimulating hormone $24.4 \mathrm{U} / 1$, luteinizing hormone $7.8 \mathrm{U} / \mathrm{l}$, oestradiol $128 \mathrm{pmol} / \mathrm{l}$, prolactin $310 \mathrm{mU} / 1$ (reference range < $400 \mathrm{mU} / \mathrm{l}$ ), IGF1 $19.6 \mathrm{mmol} / \mathrm{l}$ (reference range 12-35 mmol/l).

Dynamic testing elicited a blunted response to thyrotropin releasing hormone (TRH $400 \mu \mathrm{g}$ administered intravenously) (Table 1) and a failure to suppress TSH secretion in response to administration of $\mathrm{T}_{3}(20 \mu \mathrm{g}$ orally four times daily for 8 days) (Table 2). $\alpha$-subunit to TSH molar ratio was $4.2 \mu \mathrm{g} / \mathrm{mU}$, below the cut-off of $5.5 \mu \mathrm{g} / \mathrm{mU}$ proposed for normogonadotrophic pre-menopausal females (2). There was no evidence of co-secretion of other pituitary hormones.

MRI of pituitary illustrated a pituitary macroadenoma (maximal diameter $21 \mathrm{~mm}$ ) abutting the optic chiasm (Fig. 1A). A test regimen of octreotide $100 \mu \mathrm{g}$ three times daily for 3 days resulted in suppression of TSH secretion (Table 3).

\section{Treatment}

After multidisciplinary discussion this woman was commenced on octreotide for a period of 3 months with the aim of inducing clinical and biochemical euthyroidism prior to transsphenoidal resection of her pituitary macroadenoma. Octreotide therapy resulted in normalisation of thyroid biochemistry (free $\mathrm{T}_{4} 10.6 \mathrm{pmol} / \mathrm{l}$, TSH $0.866 \mathrm{mU} / \mathrm{l})$, a resolution of clinical symptoms and a reduction in tumour size demonstrated on MRI (Fig. 1B) (The mass had reduced in size from 21 to $11 \mathrm{~mm}$ and was no longer abutting the optic chiasm, with an estimated reduction in tumour volume of $35 \%$ based on calculation using volumetric software). Octreotide was discontinued following surgery.

Table 1 TRH test. Blunted response to administration of $400 \mu \mathrm{g}$ TRH intravenously. A normal response is an increase in $\mathrm{TSH}$ to $>5 \mathrm{mU} / \mathrm{l}$ or $>200 \%$ with the peak at $20 \mathrm{~min}$. In patients with thyroid hormone resistance, there is always an increase in $\mathrm{TSH}$, which is usually exaggerated (12).

\begin{tabular}{l} 
Time (min) after administration \\
of TRH \\
\hline 0 \\
20 \\
60 \\
\hline
\end{tabular}

\begin{tabular}{c}
\hline TSH $(\mathrm{mU} / \mathrm{l})$ \\
\hline 2.590 \\
2.595 \\
2.874
\end{tabular}

Table $2 \mathrm{~T}_{3}$ suppression test. Failure to suppress TSH secretion in response to $20 \mu \mathrm{g} \mathrm{T}_{3}$ orally four times daily for 8 days. This is in keeping with autonomous TSH secretion. A normal response is a complete suppression of $\mathrm{T}_{4}$ and TSH (12).

\begin{tabular}{|c|c|c|}
\hline Time & Free $\mathbf{T}_{\mathbf{4}}(\mathrm{pmol} / \mathrm{l})$ & TSH (mU/l) \\
\hline 0 & 25.1 & 2.5 \\
\hline 8 days & 16.4 & 2.1 \\
\hline
\end{tabular}

\section{Outcome and follow-up}

Following surgery, the patient had a transient period of diabetes insipidus with an otherwise uneventful postoperative course. Histological appearances were characteristic of a TSH-secreting pituitary adenoma (Fig. 2). At 3 months post-surgery, she remained clinically and biochemically euthyroid (free $\mathrm{T}_{4} 12.1 \mathrm{pmol} / \mathrm{l}$, TSH 0.930) with normal responses of other pituitary axes to dynamic testing. Repeat MRI demonstrated a residual pituitary mass of $6 \mathrm{~mm}$ in maximal diameter. A repeat $\mathrm{T}_{3}$ suppression test showed persistent failure to completely suppress TSH secretion in response to $\mathrm{T}_{3}$ (Table 4 ).

\section{Discussion}

The differential diagnosis of the syndrome of inappropriate TSH secretion is non-thyroidal illness, medications, assay interference due to heterophilic antibodies, thyroid hormone resistance and TSH-secreting pituitary adenoma. Repeating sample analysis using an alternative assay should elicit a different result in the case of assay interference. However, use of an alternative assay methodology

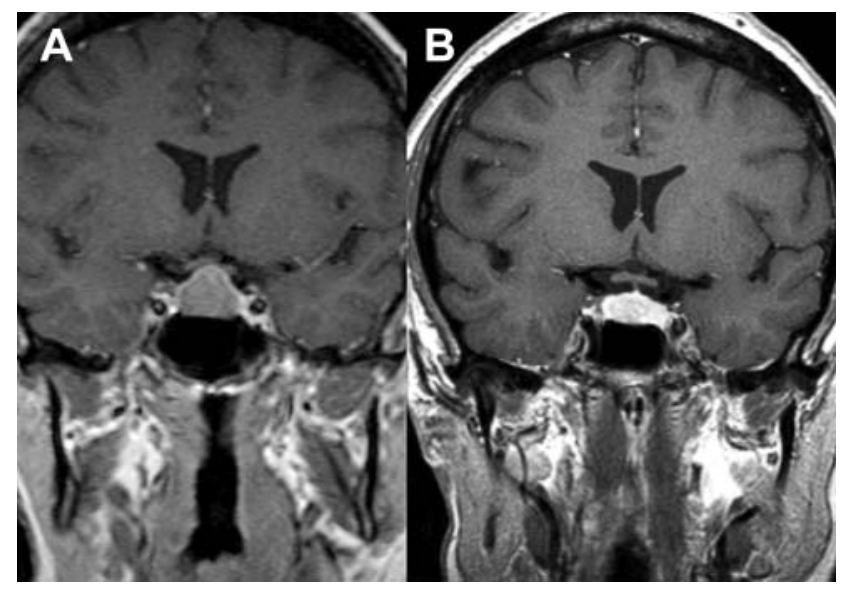

Figure 1

MRI coronal section illustrating a pituitary mass abutting the optic chiasm before octreotide therapy (A) and (B) after 3 months octreotide therapy illustrating a $35 \%$ reduction in volume of the pituitary mass. 
Table 3 Results after $72 \mathrm{~h}$ trial of octreotide, showing a reduction in both $\mathrm{T}_{4}$ and TSH concentrations.

\begin{tabular}{|c|c|c|}
\hline Time & Free $\mathbf{T}_{\mathbf{4}}(\mathrm{pmol} / \mathrm{l})$ & TSH $(\mathrm{mU} / \mathrm{l})$ \\
\hline Prior to 1 st dose & 18.8 & 3.150 \\
\hline $1 \mathrm{~h}$ post $1 \mathrm{st}$ dose & 18.0 & 2.290 \\
\hline Day 4 & 13.0 & 0.033 \\
\hline
\end{tabular}

such as PEG precipitation or equilibrium dialysis may be required to exclude assay interference. Patients are classically euthyroid in thyroid hormone resistance (with in some cases palpitations) and hyperthyroid in the case of TSH-secreting pituitary adenomas. Assessment of peripheral thyroid hormone activity (SHBG, angiotensin converting enzyme, cholesterol concentrations, and basal metabolic rate) can have utility in differentiating these states with increased activity seen in TSH-secreting pituitary adenoma and normal or decreased in thyroid hormone resistance. Dynamic testing is performed using the TRH test, which is classically blunted in TSH-secreting pituitary adenoma and the $T_{3}$ suppression test, where there is failure to completely suppress TSH secretion in the case of TSH-secreting pituitary adenomas. In contrast to thyroid hormone resistance where there is classically a normal or exaggerated response to TRH stimulation and complete TSH inhibition following $\mathrm{T}_{3}$ administered as a suppression test (1).

Management of TSH-secreting pituitary adenomas is principally via surgical adenomectomy. Postoperative external irradiation is a frequent adjunctive therapy (1). Somatostatin analogues are now the cornerstone of medical therapy. However their use has primarily been in palliative cases or in those without cure following surgery. Suppression of TSH secretion in $>90 \%$, a normalisation of free thyroid hormone concentrations in $70 \%$

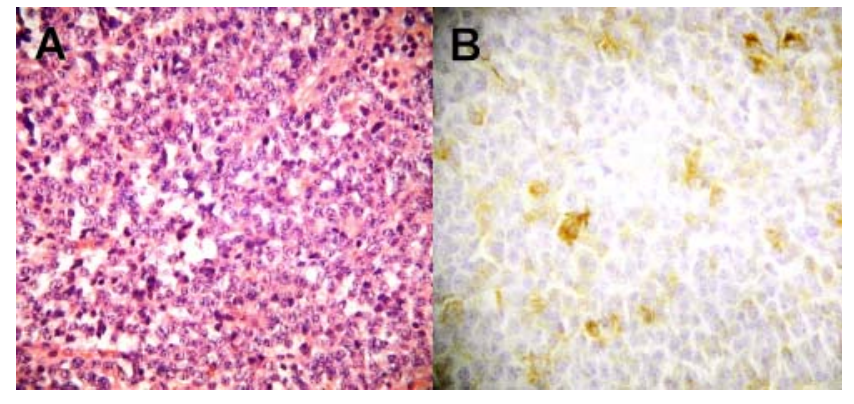

\section{Figure 2}

Histology of resected pituitary tissue. (A) Haematoxylin and eosin stain showing chromophobe adenoma tissue completely replacing normal pituitary tissue. (B) Immunohistochemical staining showing cells staining positive for TSH.
Table 4 Post-operative $T_{3}$ suppression test. Failure to suppress TSH secretion in response to $\mathrm{T}_{3} 20 \mu \mathrm{g}$ orally four times daily for 8 days. This is in keeping with a degree of residual autonomous TSH secretion (12).

\begin{tabular}{l} 
Time \\
\hline 0 days \\
\hline
\end{tabular}

\begin{tabular}{c}
\hline Free $\mathbf{T}_{\mathbf{4}}(\mathrm{pmol} / \mathrm{l})$ \\
\hline 16.6 \\
12.1 \\
\hline
\end{tabular}

\begin{tabular}{c}
\hline TSH $(\mathrm{mU} / \mathrm{l})$ \\
\hline 1.56 \\
0.93
\end{tabular}

and a reduction in tumour size in $\sim 50 \%$ of cases has been reported (3)(4). Pre-operative use has been infrequently described (5).

Somatostatin analogues exert their effects via interactions with somatostatin receptors (sstr). It is postulated that effects on TSH secretion are mediated via interactions with sstr2 and that tumour size reduction is effected via interactions with sstr5. Potentially only those tumours expressing sstr5 will reduce in size in response to a somatostatin analogue (6)(7).

The use of pre-operative somatostain analogue has been described in the management of patients with acromegaly, with some centres using somatostatin analogue therapy as primary treatment, some for a period of three to 6 months pre-operatively and some only if there is no biochemical cure following surgery. A reduction of tumour size has also been described. Current guidance states that there is presently insufficient evidence to recommend pre-surgical somatostatin analogue use routinely for improved surgical outcome or post-operative complications in the management of acromegaly (8)(9)(10). In a recent Endocrine Society clinical practice guideline pre-operative use of somatostain analogue is suggested in patients with severe pharyngeal thickness, sleep apnoea or high output cardiac failure to reduce surgical risk (11).

TSH-secreting pituitary adenoma is much more rare with less experience of the use of somatostatin analogue therapy. In a recent longitudinal Dutch study, of 18 patients followed for a median of 7 years, three were treated exclusively with somatostatin analogue and $72 \%$ required medical therapy (mostly after surgery) (12).

Whilst our case is symptomatically and biochemically euthyroid following surgery, failure to completely suppress TSH secretion in response to $\mathrm{T}_{3}$ suggests that she is not completely cured (13). Should she relapse, therapy with a somatostatin analogue remains an option. In our case, octreotide was used with the aim of inducing euthyroidism pre-operatively. A reduction in tumour bulk (35\% reduction in volume) was also obtained (Figs 1 and 2). 
Our case highlights the differential diagnosis and investigative approach for the syndrome of inappropriate TSH secretion, and uncertainties in the management of a rare pituitary adenoma. Octreotide achieved the desired clinical and biochemical euthyroidism with the additional benefit of a reduction in tumour size. Correlation with other cases is required to assess if this effect is potentially beneficial to post-operative outcomes. We suggest, that in this rare tumour pre-operative octreotide may have a role.

\section{Declaration of interest}

The authors declare that there is no conflict of interest that could be perceived as prejudicing the impartiality of the research reported.

\section{Funding}

This research did not receive any specific grant from any funding agency in the public, commercial or not-for-profit sector.

\section{Patient consent}

Written informed consent has been obtained from the patient for publication of this anonymised case report.

\section{Author contribution statement}

All authors contributed to the clinical management of this patient. All authors contributed to the writing and editing of this case report.

\section{References}

1 Beck-Peccoz P, Brucker-Davis F, Persani L, Smallridge RC \& Weintraub BD 1996 Thyrotropin-secreting pituitary tumors. Endocrine Reviews 17 610-638. (doi:10.1210/edrv-17-6-610)

2 Beck-Peccoz P, Persani L \& Faglia G 1992 Glycoprotein hormone $\alpha$-subunit in pituitary adenomas. Trends in Endocrinology and Metabolism 3 41-45. (doi:10.1016/1043-2760(92)90041-X)
3 Chanson P, Weintraub BD \& Harris AG 1993 Octreotide therapy for thyroid-stimulating hormone-secreting pituitary adenomas: a follow-up of 52 patients. Annals of Internal Medicine 119 236-240. (doi:10.7326/0003-4819-119-3-199308010-00010)

4 Beck-Peccoz P \& Persani L 2002 Medical management of thyrotropinsecreting pituitary adenomas. Pituitary 5 83-88. (doi:10.1023/ A:1022360414062)

5 Iglesias P \& Diez JJ 1998 Long-term preoperative management of thyrotropin-secreting pituitary adenoma with octreotide. Journal of Endocrinological Investigation 21 775-778. (doi:10.1007/BF03348045)

6 Horiguchi K, Yamada M, Umezawa R, Satoh T, Hashimoto K, Tosaka M, Yamada S \& Mori M 2007 Somatostatin receptor subtypes mRNA in TSH-secreting pituitary adenomas: a case showing a dramatic reduction in tumor size during short octreotide treatment. Endocrine Journal 54 371-378. (doi:10.1507/endocrj.K06-177)

7 Yoshihara A, Isozaki O, Hizuka N, Nozoe Y, Harada C, Ono M, Kawamata T, Kubo O, Hori T \& Takano K 2007 Expression of type 5 somatostatin receptor in TSH-secreting pituitary adenomas: a possible marker for predicting long-term response to octreotide therapy. Endocrine Journal 54 133-138. (doi:10.1507/endocrj.K06-133)

8 Melmed S, Colao A, Barkan A, Molitch M, Grossman AB, Kleinberg D, Clemmons D, Chanson P, Laws E, Schlechte J et al. 2009 Guidelines for acromegaly management: an update. Journal of Clinical Endocrinology and Metabolism 94 1509-1517. (doi:10.1210/jc.2008-2421)

9 Katznelson L, Atkinson JL, Cook DM, Ezzat SZ, Hamrahian AH \& Miller KK 2011 American Association of Clinical Endocrinologists medical guidelines for clinical practice for the diagnosis and treatment of acromegaly - 2011 update. Endocrine Practice 17 S1-S44. (doi:10.4158/EP.17.S4.1)

10 Jacob JJ \& Bevan JS 2014 Should all patients with acromegaly receive somatostatin analogue therapy before surgery and, if so, for how long? Clinical Endocrinology 81 812-817. (doi:10.1111/cen.12553)

11 Katznelson L, Laws ET, Melmed S, Molitch ME, Murrad MH, Utz A \& Wass JAH 2014 Acromegaly: an Endocrine Society clinical practice guideline. Journal of Clinical Endocrinology and Metabolism 99 3933-3951. (doi:10.1210/jc.2014-2700)

12 Van Varsseveld NC, Bisschop PH, Biermasz NR, Pereira AM, Fliers E \& Drent ML 2014 A long-term follow-up study of eighteen patients with thyrotrophin-secreting pituitary adenomas. Clinical Endocrinology $\mathbf{8 0}$ 395-402. (doi:10.1111/cen.12290)

13 Brucker-Davis F, Oldfield EH, Skarulis MC, Doppman JL \& Weintraub BD 1999 Thyrotropin-secreting pituitary tumors: diagnostic criteria, thyroid hormone sensitivity and treatment outcome in 25 patients followed at the National Institutes of Health. Journal of Clinical Endocrinology and Metabolism 84 476-486. (doi:10.1210/jcem. 84.2.5505)

Received in final form 11 May 2015 Accepted 21 May 2015 